\title{
Analisis Character, Capacity, Capital, Collateral Dan Condition Dalam Efektivitas Pembiayaan Pada Koperasi Simpan Pinjam Di Kota Palopo
}

\author{
Zainuddin $\mathrm{S}^{1}$, Sitti Anugrahwati $\mathrm{S}^{2}$., Mujahidin ${ }^{3}$ \\ Institut Agama Islam Negeri ${ }^{123}$ \\ E-mail: Zainuddin@iainkendari.ac.id ${ }^{1}{ }^{\text {mujahidin@iainkendari.ac.id }{ }^{3}}$
}

\begin{abstract}
Abstrak
Eksistensi Perkembangan koperasi simpan pinjam di kota palopo sebagai salah satu lembaga pembiayaan mikro bagi pelaku usaha kecil dan menengah sangat memberikan kontribusi kepada pertubuhan Ekonomi dengan menawarkan produk pembiayaan yang mengandung risiko pengembalian yang cukup besar sehingga di butuhkan kemampuan analisis penilaian terhadap calon Nasabah dengan tujuan untuk mengetahui kelayakan pembiayaan yang akan disalurkan. Hasil penelitian ini menunjukkan bahwa implementasi analisis character, capacity, capital, collateral dan condition yang berkaitan dengan pencegahan atau meminimalisir resiko pembiayaan bermasalah dalam penilaian kelayakan pemberian pembiayaan pada koperasi simpan pinjam di Kota Palopo telah menerapkan prosedur penilaian syarat kelayakan calon nasabah. Namun demikian mash terdapat kelemahan dalam proses analisis calon Nasabah dikarenakan kurangnya kompetensi sumberdaya manusia dalam menawarkan produk pembiayaan dengan tingkat rosiko cukup besar,
\end{abstract}

Kata Kunci : Analisis 5C, Efektivitas Pembiayaan 


\section{PENDAHULUAN}

Saat ini, kehidupan ekonomi telah menjadi standar kehidupan individu dan kolektif suatu negara. Keunggulan suatu negara diukur berdasarkan tingkat kemajuan ekonomi. Salah satu fasilitas yang memiliki peran strategis dalam kegiatan ekonomi adalah koperasi.

Menurut Undang-Undang Nomor 17 Tahun 2012 tentang perkoperasian, koperasi adalah badan hukum yang didirikan oleh perorangan, perseorangan atau badan hukum. Dengan pemisahan kekayaan anggotanya sebagai modal untuk menjalankan usaha, yang dapat memenuhi aspirasi umum dan kebutuhan di bidang ekonomi, sosial dan budaya sesuai dengan nilai-nilai dan prinsip koperasi. (Larto, 2012)

Secara umum, alokasi dana yang paling tepat dan menguntungkan adalah dalam bentuk kredit atau pembiayaan. Namun, risiko yang dihadapi oleh koperasi dalam mengalokasikan dana dalam bentuk ini juga besar. Sebelum fasilitas kredit diberikan, pengelola koperasi harus merasa yakin bahwa kredit atau pembiayaan yang diberikan benar-benar kembali. Keyakinan ini muncul dari hasil penilaian pembiayaan yang baik dan benar.

Koperasi tidak dapat dipisahkan dari masalah kredit atau pembiayaan ini, dan bahkan menjadi aneh jika koperasi tidak memiliki masalah kredit kecuali koperasi tersebut baru didirikan. Penulis memiliki pandangan bahwa analisis character, capacity, capital, collateral, dan condition belum efektif diterapkan pada Koperasi Simpan Pinjam di Kota Palopo. Hal ini dapat dilihat dari kecenderungan Koperasi Simpan Pinjam di Kota palopo yang masih memiliki kredit atau pembiayaan kurang lancar dan bahkan kredit macet. Kemacetan kredit adalah masalah yang menyebabkan kesulitan bagi koperasi, terutama menyangkut tingkat kesehatan koperasi, karena koperasi wajib menghindari kredit macet. Penulis bermaksud untuk menganalisis efektivitas pembiayaan pada Koperasi Simpan Pinjam di Kota Palopo dengan menggunakan analisis character, capacity, capital, collateral, dan condition.

Tujuan utama analisis pembiayaan yaitu menilai kemampuan dan kemauan calon nasabah untuk mengembalikan kewajiban mereka sesuai dengan perjanjian 
awal. Berdasarkan analisis pembiayaan pengelola koperasi dapat memperkirakan tingkat risiko yang akan ditanggung oleh koperasi jika menyetujui permohonan yang diajukan oleh calon nasabah dan koperasi mengetahui kondisi keseluruhan calon nasabah untuk meminimalkan tingkat risiko pembiayaan.

Layak atau tidak seseorang untuk diberikan pembiayaan, dapat dilakukan dengan mempertimbangkan aspek sebagai berikut: character, capacity, capital, collateral dan condition. Aspek character dalam hal ini berkaitan dengan keyakinan bahwa sifat atau karakter orang yang akan diberikan kredit benar-benar dapat dipercaya. Aspek capacity berkaitan dengan calon debitur dalam kemampuannya dalam bidang bisnis yang terkait dengan pendidikannya. Aspek capital terkait dengan faktor penggunaan modal yang efektif, dilihat dari bagaimana menempatkan dana dalam mengembangkan usahanya, bagaimana perkembangan modal kerja dan antisipasinya untuk mengembalikan pinjaman. Aspek collateral terkait dengan jaminan yang diberikan oleh calon nasabah aspek fisik dan non-fisik yaitu kepercayaan yang terbangun antara pengelola koperasi dengan calon nasabah. Aspek condition dinilai dengan melihat kondisi ekonomi dan politik saat ini dan masa depan sesuai dengan sektor masing-masing, serta prospek bisnis yang dijalankan. Setelah melakukan analisis mengenai aspek character, capacity, capital, collateral dan condition, maka pengelola koperasi akan memutuskan apakah calon nasabah memenuhi syarat atau tidak untuk diberikan pembiayaan. (Kasmir, 2002)

Berdasarkan pemaparan maka penulis merumuskan masalah dalam penelitian yaitu (1) Bagaimana implementasi analisis character, capacity, capital, collateral dan condition pada pemberian pembiayaan pada koperasi simpan pinjam di Kota Palopo; dan (2) Bagaimana mengefektifkan pembiayaan pada koperasi simpan pinjam di Kota Palopo dengan menggunakan analisis character, capacity, capital, collateral dan condition.

\section{METODE PENELITIAN}

Pendekatan penelitian ini adalah kualitatif dengan menggunakan jenis penelitian kualitatif deskriptif. Objek dalam penelitian ini yaitu koperasi simpan 
pinjam di kota Palopo. Informan dalam penelitian yaitu karyawan koperasi simpan pinjam di Kota Palopo. Teknik pengumpulan data menggunakan data primer yaitu: (1) Observasi: melakukan pengamatan secara langsung ke Koperasi Simpan Pinjam di Kota Palopo sehingga memperoleh informasi yang terkait dengan penelitian, (2) Wawancara: dengan melakukan wawancara bersama pihak koperasi simpan pinjam di kota Palopo dengan menggunakan alat panduan wawancara tersebut dapat diperoleh keterangan untuk penelitian. (3) Dokumentasi: mengambil data-data dokumentasi dapat membantu dalam memecahkan masalahmasalah penelitian dan menjadi bukti penguat informasi. Data sekunder yaitu didapat dari artikel atau juenal yang terkait dengan analisis character, capacity, capital, collateral dan condition. Data dianalisis dengan menggunakan teknik reduksi data, penyajian data dan penarikan kesimpulan.

\section{HASIL PENELITIAN DAN PEMBAHASAN}

a. Analisis 5C (character, capacity, capital, collateral dan condition) sebagai dasar persetujuan pemberian pembiayaan. Berikut ketentuan-ketentuan yang harus mendapat penilaian yang baik oleh pihak koperasi simpan pinjam:

\section{1) Character}

Character yaitu sifat atau karakter calon nasabah baik yang berkaitan dengan kehidupan pribadi maupun usaha, karakter atau sifat calon nasabah sangat menentukan itikat baik dalam melakukan sesuatu terutama dalam hal pinjam meminjam. Dalam islam juga menuntut seseorang memiliki sifat atau karakter yang baik lagi mulia.

Hal tersebut berdasarkan teori yang dikemukakan oleh Kasmir yang menyatakan bahwa Character merupakan suatu keyakinan bahwa sifat atau watak dari orang-orang yang akan diberikan kredit benar-benar dapat dipercaya. Mencari tahu sifat-sifat calon debitur, menggunakan analisis yang lebih cenderung merupakan analisis kualitatif yang tidak terbaca diangka-angka yang disajikan untuk mengetahui itikad baik dari debitur. (Kasmir, 2002) 
Hal tersebut juga telah tergambar dalam QS. Ibrahim/ $14: 24-25$

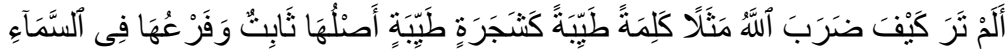

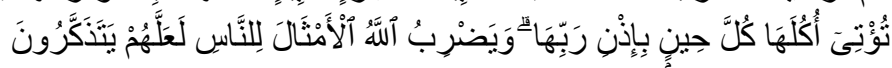

Terjemahannya: Tidakkah kamu perhatikan bagaimana Allah telah membuat perumpamaan kalimat yang baik seperti pohon yang baik, akarnya teguh dan cabangnya (menjulang) ke langit. Pohon itu memberikan buahnya pada setiap musim dengan seizin Tuhannya. Allah membuat perumpamaan-perumpamaan itu untuk manusia supaya mereka selalu ingat.(QS. Ibrahim/14 : 2425). (Departemen Agama Republik Indonesia, 2001)

Berdasarkan ayat tersebut menyerukan bahwa karakter baik itu tidak hanya

digambarkan dalam perkataan tetapi juga melalui yang diwujudkan dalam perbuatan.

Berdasarkan hasil interview (wawancara) yang dilakukan dengan para pihak koperasi simpan pinjam yang ada di kota Palopo, mereka menyatakan bahwa dalam menganalisis character calon nasabah ini mereka melakukan survei untuk membangun kepercayaan kepada calon nasabah dan melakukan analisis kelayakan apakah calon nasabah tersebut layak diberikan pembiayaan atau tidak.

Character yaitu sifat atau karakter calon nasabah baik yang berkaitan dengan kehidupan pribadi maupun usaha, karakter atau sifat calon nasabah sangat menentukan itikat baik dalam melakukan sesuatu terutama dalam hal pinjam meminjam. Dalam islam juga menuntut seseorang memiliki sifat atau karakter yang baik lagi mulia.

Hal tersebut berdasarkan teori yang dikemukakan oleh Kasmir yang menyatakan bahwa Character merupakan suatu keyakinan bahwa sifat atau watak dari orang-orang yang akan diberikan kredit benar-benar dapat dipercaya. Mencari tahu sifat-sifat calon debitur, menggunakan analisis yang lebih cenderung merupakan analisis kualitatif yang tidak terbaca diangka-angka yang disajikan untuk mengetahui itikad baik dari debitur. (Kasmir, 2002) 
Hal tersebut juga telah tergambar dalam QS. Ibrahim/ 14 : 24-25

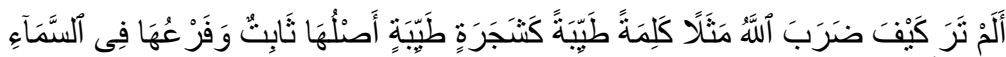

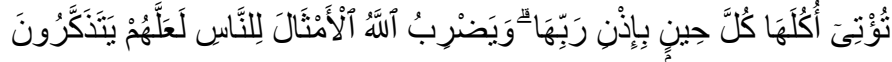

Terjemahannya: Tidakkah kamu perhatikan bagaimana Allah telah membuat perumpamaan kalimat yang baik seperti pohon yang baik, akarnya teguh dan cabangnya (menjulang) ke langit. Pohon itu memberikan buahnya pada setiap musim dengan seizin Tuhannya. Allah membuat perumpamaan-perumpamaan itu untuk manusia supaya mereka selalu ingat.(QS. Ibrahim/14 : 2425). (Departemen Agama Republik Indonesia, 2001)

Berdasarkan ayat tersebut menyerukan bahwa karakter baik itu tidak hanya digambarkan dalam perkataan tetapi juga melalui yang diwujudkan dalam perbuatan.

Berdasarkan hasil interview (wawancara) yang dilakukan dengan para pihak koperasi simpan pinjam yang ada di kota Palopo, mereka menyatakan bahwa dalam menganalisis character calon nasabah ini mereka melakukan survei untuk membangun kepercayaan kepada calon nasabah dan melakukan analisis kelayakan apakah calon nasabah tersebut layak diberikan pembiayaan atau tidak.

Menurut beberapa pihak koperasi simpan pinjam yang ada di kota Palopo bahwa karakter calon nasabah ini tidak bisa dinilai dan terkadang memberikan informasi yang kurang tepat sehingga data yg diterima tidak valid, sehingga kita tidak bisa memperkirakan apakah calon nasabah tersebut dapat mengangsur pinjamannya dengan lancar atau tidak.

Penerapan analisis character pada koperasi simpan pinjam di Kota Palopo belum sepenuhnya memenuhi prinsip dalam melakukan survei di lapangan. pengelola koperasi belum melakukan penilaian maksimal terhadap character calon nasabah dan tidak memaksimalkan waktu yang di sediakan untuk menganalisis calon nasabah secara lebih mendalam. Sehingga kedekatan secara personal tidak terbangun dengan calon nasabah. Hal tersebut yang menyebabkan mekanisme pembiayaan masih kurang efektif.

2) Capacity 
Penilaian aspek ini harus teliti dalam menilai bagaimana kemampuan calon debitur dalam membayar kewajibannya. Dengan maksud bahwa berarti penghasilan bersih yang diperoleh setiap bulan, jumlahnya harus lebih besar dari angsuran pembiayaan yang harus dibayar pada setiap bulannya. Analisis ini meliputi pendapatan, pengeluaran, besar dan jangka waktu angsuran calon nasabah.

Hal tersebut berdasarkan teori yang dikemukakan oleh Kasmir yang menyatakan bahwa capacity digunakan untuk melihat kemampuan nasabah yang mengajukan kredit dalam bidang bisnis yang dihubungkan dengan kemampuannya untuk menjalankan usaha. Penilaian ini digunakan untuk melihat kemampuan nasabah dalam mengembalikan kredit yang diberikan. (Kasmir, 2002)

Jika seorang nasabah tidak mampu memenuhi kewajiban yang disebabkan ketidakmampuan bayar maka pihak koperasi memberikan jangka waktu pelunasan kepada nasabah. Jika belum mampu juga maka pihak koperasi harus menarik jaminan sesuai dengan kesepakatan awal penerimaan pembiayaan.

Berdasarkan hasil wawancara yang telah dilakukan dengan ibu Desi Setiawati selaku bagian administrasi pada Koperasi Mitra Duafa Cabang Palopo, menyatakan bahwa analisis capacity atau kemampuan bayar calon nasabah ini dapat dilihat pada usaha calon nasabah. Seberapa besar hasil yang didapatkan dari usaha tersebut kemudian disesuaikan dengan jumlah pembiayaan dan jangka waktu angsuran yang akan diberikan. Namun demikian data yang diperoleh tidak memenuhi unsur pendapatan real nasabah dimana tidak terdapat data laporan keuangan yang menjadi pertimbangan dalam pengemabilan keputusan bagi manajemen

Tujuan menganalisis capacity calon debitur seberapa besar kemampuan calon nasabah dalam memenuhi kewajibannya dilihat dari penghasilan bersih calon nasabah. Sehingga pihak koperasi harus melakukan penilaian mendalam mengenai terhadap kemampuan bayar atau capacity calon nasabah.

3) Capital 
Capital atau modal yang perlu disertakan dalam objek pembiayaan dan mesti dilakukan analisis yang lebih mendalam dikarenakan analisis ini cukup berpengaruh terhadap keputusan pemberian pembiayaan demi kelancaran nasabah dalam memenuhi kewajibannya, sehingga pihak koperasi dapat meminimalisir terjadinya pembiayaan bermasalah.

Hal tersebut berdasarkan teori yang dikemukakan oleh Tiktik Sartika Parmono dan Abd. Rachman Soejoedono yang menyatakan bahwa besarnya modal yang dimiliki dan yang akan diperlukan serta bagaimana menempatkan dana dalam mengembangkan usaha, bagaimana perkembangan modal kerja dan antisipasinya untuk mengembalikan pinjaman. (Parmono, 2002)

Adapun cara pihak koperasi simpan pinjam di kota Palopo dalam menerapkan analisis capital yaitu dinilai dari pendapatan nasabah dalam setiap bulannya, penilaian modal kerja nasaba baik itu gaji maupun pendapatan dari usaha calon nasabah, besaran omset penjualan usaha dan lain yang berkaitan dengan upaya pelunaan pembiayaan yang akan dilaksanakan, analisis ini diterapkan sejalan dengan perintah Allah tentang permodalan dalam usaha, tercantum dalam QS. Az Zumar (39):39

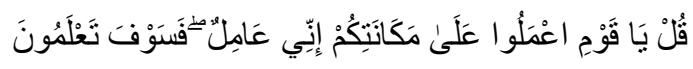

Terjemahannya: Katakanlah: "Hai kaumku, bekerjalah sesuai dengan keadaanmu, sesungguhnya aku akan bekerja (pula), maka kelak kamu akan mengetahui.(QS. Az-Zumar/39: 39).

Ayat tersebut menerangkan bahwa salah satu modal dari diri sendiri yaitu pekerjaan atau bekerja maka dari hal itu dapat menghasilkan penghasilan untuk menghidupi kehidupannya dengan baik. Oleh karena itu, dalam menganalisis capital calon nasabah pihak koperasi harus mengetahui berapa besaran atau jumlah modal yang dimiliki oleh calon nasabah serta bagaimana sistem pengelolaan dana dalam mengembangkan usahanya.

4) Collateral

Analisis collateral merupakan analisis yang berkaitan dengan angunan calon nasabah yang diajukan kepada pihak koperasi. Angunan yang dijaminkan dapat berupa BPKB motor/mobil, sertifikat tanah, sertifikat rumah, bahkan 
barang-barang elektronik, tergantung dari besar kecilnya pembiayaan yang diterima oleh nasabah.

Hal tersebut berdasarkan teori yang dikemukakan oleh Jopie Jusuf yang menyatakan bahwa Analisis terhadap character, capacity dan capital sebenarnya bertujuan untuk menentukan tingkat keberhasilan calon debitur mengelola bisnisnya. Bila hasil analisis menunjukkan bahwa bisnis calon debitur itu bagus, maka dikatakan bahwa risiko bisnisnya adalah rendah. Bila sebaliknya, maka risiko bisnisnya tinggi. Oleh karena itu, collateral (angunan) calon debitur inilah jalan keluar kedua dari kredit. Semua orang ingin agar kredit lunas dengan lancar. Tetapi prakteknya kadang-kadang jalan keluar pertama ini tidak selalu berjalan mulus seperti apa yang diharapkan. Untuk itu diperlukan alternatif jalan keluar lainnya, yaitu dari angunan kredit. Bila jalan pertama tidak berhasil maka pelunasan kredit dilakukan dengan melikuidasi angunan. ( Jusuf, 2014)

Semakin besar pembiayaan yang diterima maka semakin besar pula nilai angunan yang akan dijaminkan, karena angunan ini merupakan sumber pembayaran kedua apabila nasabah sudah tidak dapat memenuhi kewajibannya, maka angunan dapat digunakan sebagai bahan pelunasan namun dengan mengutamakan prinsip kekeluargaan yaitu dengan adanya kesepakatan bersama antara pihak koperasi dengan nasabah yang bersangkutan.

Berdasarkan hasil wawancara yang telah dilakukan dengan bapak Matius selaku marketing lapangan pada KSP BALO'TA (BALO' TORAJA) Cabang Palopo mengatakan bahwa, analisis collateral ini merupakan penilaian utama dalam memberikan pembiayaan dikarenakan kekuatan aset ini yang akan menjadi solusi bagi kopeasi untuk mengembalikan investasi/pembiayaan pihak koperasi jika ternyata dikemudian hari terjadi wanprestasi nasabah dalam memenuhi memenuhi kewajibannya.

\section{5) Condition}

Analisis condition calon nasabah ini yaitu pihak koperasi dapat melihat kondisi ekonomi sekitar, karena kondisi merupakan salah satu faktor penting yang dapat mempengaruhi keberlangsungan usaha yang dijalankan oleh calon nasabah. 
Jadi dengan melihat kondisi ekonomi calon nasabah, pihak koperasi dapat mempertimbangkan pengajuan pembiayaan yang dilakukan oleh calon nasabah.

Hal tersebut berdasarkan teori yang dikemukakan oleh V. Wiratna Sujarweni yang menyatakan bahwa dalam pemberian kredit kepada debitur, juga perlu diketahui kondisi ekonomi yang dikaitkan dengan prospek usaha calon debitur. Ada bisnis yang sangat tergantung pada kondisi ekonomi. Oleh karena itu, perlu menghubungkan kondisi ekonomi dengan bisnis calon debitur sehingga koperasi dapat meninjau prospek bisnis kedepan. ( Sujarweni, , 2016)

Ada beberapa penilaian yang semestinya diterapkan dalam melihat suatu kondisi ekonomi calon debitur diantaranya, lokasi usaha, sumber daya manusia, produk atau jasa yang ditawarkan, dan sebagainya. Namun, berdasarkan hasil wawancara dengan beberapa pihak koperasi simpan pinjam yang ada di kota Palopo mengatakan bahwa, penilaian kondisi ekonomi ini hanya sebatas melihat kondisi atau perkembangan usaha calon nasabah tanpa mempertimbangkan lokasi usaha, pesaing yang ada dilokasi, dan sebagainya. Dalam hal ini pihak kopeasi belum memberikan penilaian tentang bagamana prospek perkembangan usaha calan nasabah sebelum akad dilaksanakan.

Hal tersebut dikarenakan pengelola koperasi tidak memilik waktu analisis yang cukup untuk mendalami kondisi calon nasabah. Baik dari segi sumber daya manusia, persaingan melalui lokasi usaha, produk atau jasa, serta proses atau aktivitas bisnis yang dijalankan oleh calon nasabah.

Dimana hal inilah yang seharusnya menjadi penilaian dalam analisis condition yang dapat memberikan pengaruh terhadap besar kecilnya pembiayaan yang akan diberikan kepada calon nasabah, sehingga nasabah bisa memenuhi kewajibannya dengan baik.

b. Analisis upaya mengefektifkan pembiayaan pada koperasi simpan pinjam di kota Palopo dengan menggunakan analisis character, capacity, capital, collateral dan condition Upaya yang dilakukan dalam meminimalisir 
pembiayaan bermasalah yang terjadi pada koperasi tersebut merupakan sebuah langkah yang secara perlahan dapat mengurangi pembiayaan bermasalah yang terjadi pada koperasi simpan pinjam di kota Palopo selama ini. Pengawasan pembiayaan merupakan suatu usaha yang tepat dilakukan oleh pihak koperasi guna meminimalisir pembiayaan bermasalah tersebut. Koperasi merupakan ekonomi berbasis kerakyatan dan dengan kekuatan anggotanya koperasi dapat tangguh dan mandiri. Pengelolaan Koperasi yang baik tidak lepas dari Sumber Daya Manusia Pengurus maupun pengelola. Pelatihan Peningkatan SDM bagi Pengelola Koperasi selayaknya Berbasis Kompetensi sehingga tercapai tujuan koperasi, berbagai kompetensi yang butuhkan secara umum di kota Palopo diantaranya ; Mengenal struktur, fungsi dan tugas setiap perangkat organisasi koperasi, Menemukan kiat-kiat berwirausaha dengan baik, Memahami metode menganalisa masalah usaha baik dari segi organisasi maupun usaha Nasabah, Terampil dalam membuat rencana anggaran, membuat dan membaca laporan keuangan koperasi, Untuk mengembangkan keahlian sehingga pekerjaan dapat diselesaikan dengan lebih cepat dan efektif dan Untuk mengembangkan sikap sehingga menimbulkan kemauan kerjasama dalam melakukan kemitraan.

Oleh karena itu, pihak koperasi harus memaksimalkan waktu yang telah ditetapkan untuk mengalisis calon nasabah terutama dalam hal character dan condition calon nasabah, karena dua faktor ini dapat memberikan pengaruh terhadap efektivitas pembiayaan dan tingkat kemakmuran pada koperasi simpan pinjam di kota Palopo.

Menurut beberapa pihak koperasi simpan pinjam yang ada di kota Palopo bahwa karakter calon nasabah ini tidak bisa dinilai dikarenakan karakter seseorang itu dapat berubah-ubah sehingga kita tidak bisa memperkirakan apakah calon nasabah tersebut dapat mengangsur pinjamannya dengan lancar atau tidak.

Penerapan analisis character pada koperasi simpan pinjam di Kota Palopo belum sepenuhnya memenuhi prinsip dikarenakan dalam melakukan survei di lapangan pengelola koperasi belum melakukan penilaian maksimal terhadap character calon nasabah dan tidak memaksimalkan waktu yang di sediakan untuk menganalisis calon nasabah secara lebih mendalam. Sehingga kedekatan secara 
personal tidak terbangun dengan calon nasabah. Hal tersebut yang menyebabkan mekanisme pembiayaan masih kurang efektif.

\section{SIMPULAN}

Penelitian yang dilakukan oleh penulis serta analisis terhadap hasil penelitian lapangan pada koperasi simpan pinjam di Kota Palopo, maka penulis dapat menarik kesimpulan bahwa :

a. Implementasi analisis character, capacity, capital, collateral dan condition dalam penilaian kelayakan pemberian pembiayaan pada koperasi simpan pinjam di kota Palopo belum dilaksnakan dengan maksimal sesuai dengan prosedur penilaian syarat kelayakan calon nasabah untuk diberikan pembiayaan. Hal ini ditunjukan dengan berbagai kelemahan dalam melakukan Analisis character, capacity, capital, collateral dan condition berkaitan dalam pencegahan atau meminimalisir resiko pembiayaan bermasalah, diantaranya kapasitas sumber daya manusia, waktu pelaksanaan analisis sangat singkat, data yang diperoleh masih kurang valid.

b. Analisis character, capacity, capital, collateral dan condition memiliki peranan yang sangat penting dalam upaya meminimalisir terjadinya pembiayaan bermasalah. Sehingga dalam upaya meningkatkan efektivitas pembiayaan dengan melaksanakan pelatihan sumberdaya manusia yang dimiliki, penilaian usaha/kondisi nasabah beserta lingkungannya, meminimalisir resiko wanprestasi dengan analisis perkembangan usaha calon Nasabah, melakukan pengawasan pelaksanaan pembiayaan, dan pembinaan nasabah dalam pengelolaan usaha.

\section{SARAN}

Adapun saran-saran yang dapat diberikan yang bertujuan untuk kebaikan dan kemajuan koperasi simpan pinjam di kota Palopo adalah sebagai berikut.

a. Praktisi 
1) Diharapkan dalam menganalisis character, capacity, capital, collateral dan condition harus lebih matang, terutama pada character dan condition agar dalam upaya pencegahan pembiayaan bermasalah lebih maksimal.

2) Disarankan agar melakukan on the spot juga terhadap pegawai sehingga dalam menilai condition dan character sangat maksimal dan meminimalisir kesalahan yang akan terjadi.

3) Disarankan agar lebih prudential dalam menerapkan analisis character, capacity, capital, collateral dan condition baik kepada calon nasabah maupun pegawai koperasi karena hal ini merupakan faktor yang sangat penting dalam menilai dan menseleksi calon nasabah.

b. Peneliti

Peneliti untuk kedepannya diharapkan agar kiranya hasil yang didapatkan bisa dijadikan sebagai bahan referensi untuk suatu penelitian berikutnya, serta sebaiknya ada tambahan pengembangan objek yang belum diteliti serta untuk peneliti yang kedepannya diharapkan agar mempersiapkan diri ketika dalam proses pengumpulan dan pengambilan data melalui sumber yang kompeten.

\section{DAFTAR PUSTAKA}

Anisa, Nur. "Analisis Prinsip 5C Calon Debitur Dan Pengawasan Pembiayaan (Monitoring) Terhadap Efektivitas Pemberian Pembiayaan Pada KSPS BMT Yogyakarta.” UIN Sunan Kalijaga, 2017.

Diman, Hadi Ismanto dan Tohir. "Analisis Efektivitas Pemberian Pinjaman Program Pembiayaan UMKM Oleh Koperasi.” Economia 102014.

Hasanuddin, Maulana and Jaih Mubarok. Perkembangan Akad Musyarakah. Jakarta: kencana, 2012.

Indonesia, Departemen Agama Republik. Al-Qur'an Al-Karim Dan Terjemahan. Semarang, 2001.

Jusuf, Jopie. Analisis Kredit Untuk Credit (Account) Officer. Jakarta: Gramedia Pustaka Utama, 2014.

Kasmir. Bank Dan Lembaga Keuangan Lainnya. Jakarta: PT. Raja Grafindo Persada Kurniasih, 2002. 
Larto. Koperasipreneur Jadi Pengusaha Muda Anti Bangkrut. Jakarta: Naga Media, 2012.

Nasional, Departemen Pendidikan. Kamus Bahasa Indonesia. 4th ed. Jakarta: Gramedia, 2008.

Purnamasari, Indah. "Analisis Efektivitas Dan Faktor-Faktor Pengambilan Pembiayaan Usaha Mikro Dan Kecil Pada Lembaga Keuangan Mikro Syariah.” Institut Pertanian Bogor, 2011.

Ruwati, and Pandi Afandi. "Persepsi Nasabah Pada Aspek 5C Untuk Menentukan Kelayakan Pemberian Kredit Pada Nasabah Pt. Bpr Nusamba Ampel Cabang Salatiga." Stie Semarang 6 (2014).

Saraswati, Rosita Ayu. "Peranan Analisis Laporan Keuangan, Penilaian Prinsip 5C Calon Debitur Dan Pengawasan Kredit Terhadap Efektivitas Pemberian Kredit Pada PD BPR Bank Pasar Kabupaten Temanggung.” Nominal 1 (2012).

Sarifudin, Muhamad. "Analisis Efektivitas Pembiayaan Musyarakah Dalam Meningkatkan Pendapatan Nasabah BPRS Metro Madani, Kota Metro." Institut Agama Islam Negeri Raden Intan, 2017.

Sattar. Buku Ajar Ekonomi Koperasi. Yogyakarta: CV Budi Utama, 2017.

Setiawan, Albi Anggito dan Johan. Metode Penelitian Kualitatif. 1st ed. Jakarta: CV Jejak, 2018.

Shadily, John M. Echols dan Hassan. Kamus Inggris Indonesia. Jakarta: Gramedia, 2003.

Sholihat, Tanjung, Gustiawati. "Analisis Efektivitas Pembiayaan Lembaga Keuangan Mikro Syariah Terhadap Perkembangan Usaha Naabah Di Sektor Rill (Usaha Mikro, Kecil Dan Menengah)." Sholihat, Tanjung, Gustiawati 6 2015.

Sholihin, Ahmad Ifham. Buku Pintar Ekonomi Syariah. 1st ed. Jakarta: Gramedia Pustaka Utama, 2000.

Siregar, Elfi Rahmayani. "Analisis Implementasi 5C Pada Pembiayaan Murabahah.” Institut Agama Islam Negeri Raden Intan, 2017.

Sitio, Arifin and Halomoan Tamba. Koperasi Teori dan Praktik. Jakarta: erlangga, 2001.

Sugiyono. Metode Penelitian Kuantitatif, Kualitatif, Dan $R \& D .1$ st ed. Bandung: Alfabeta, 2017. 
Sujarweni, V. Wiratna. Manajemen Keuangan Teori, Aplikasi Dan Hasil Penelitian. Yogyakarta: Pustaka Baru Press, 2016. -. Metodologi Penelitian. 1st ed. Yogyakarta: Pustaka Baru Press, 2014.

Tanjung, M. Azrul. Koperasi Dan UMKM Sebagai Fondasi Perekonomian Indonesia. Jakarta: Erlangga, 2017.

Tiktik Sartika Parmono, Abd. Rachman Soejoedono. Ekonomi Skala Kecil/ Menengah Dan Koperasi. Jakarta: Ghalia Indonesia, 2002.

Tirmidzi/ Abu I'sa Muhammad bin I'sa bin Saurah. 1994. Kitab : Hukum-hukum. juz 3. Darul Fikri/ Bairut-Libanon. 
Volume 03 Nomor 012021 : page 64-78 alektiangl.

p-ISSN: 2686-262X e-ISSN : 2685-9300

DOI : 10.24256 